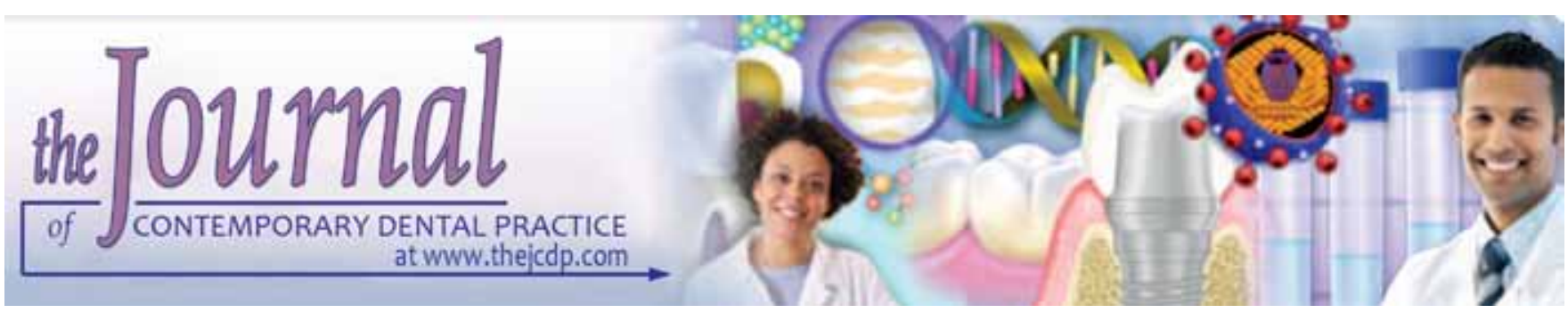

\title{
Orthodontic Extrusion as Treatment Option for Crown- Root Fracture: Literature Review with Systematic Criteria
}

\author{
${ }^{1}$ Lorraine Perciliano de Faria, ${ }^{2}$ Melyna Marques de Almeida, ${ }^{3}$ Marina Fuzette Amaral \\ ${ }^{4}$ Eduardo Piza Pellizzer, ${ }^{5}$ Roberta Okamoto, ${ }^{6}$ Marcos Rogério Mendonça
}

\begin{abstract}
Objective: To review the literature searching for a consensus for the choice of orthodontic extrusion as treatment for crownroot fracture.

Materials and methods: An electronic search was performed in the databases PubMed, Cochrane Central Register of Controlled Trials and Scopus and a manual search of the Journal Dental Traumatology.

Results: Forty articles were found in PubMed and 38 in Scopus and after removal of duplicate sample 51 contained articles. Of these, 48 were excluded for not having orthodontic treatment, no follow-up or follow-up less than 6 months, or not report the presence of crown-root fracture. In manual search in Dental Traumatology 20 articles were found, but none of them met the prerequisites established. So, three articles formed the basis of the study.
\end{abstract}

Conclusion: The choice of how to treat orthodontic extrusion of crown-root fracture was effective and stable, without root and periodontal changes. Factors, such as root formation and presence of pulp vitality were decisive for determining the stages of treatment, however, there is no consensus based on scientific evidence about these protocols.

Keywords: Orthodontic extrusion, Orthodontics, Tooth injuries.

How to cite this article: de Faria LP, de Almeida MM, Amaral MF, Pellizzer EP, Okamoto R, Mendonça MR. Orthodontic Extrusion

\footnotetext{
${ }^{1,6}$ Department of Pediatric and Community Dentistry, Dentistry School of Araçatuba-UNESP, Araçatuba, São Paulo, Brazil

2,3,5Department of Surgery and Integrated Clinic, School Dentistry of Araçatuba-UNESP, Araçatuba, São Paulo, Brazil

${ }^{4}$ Department of Dental Materials and Prosthodontics, School Dentistry of Araçatuba-UNESP, Araçatuba, São Paulo, Brazil

Corresponding Author: Lorraine Perciliano de Faria, Masters Student, Department of Pediatric and Community Dentistry Dentistry School of Araçatuba-UNESP, Araçatuba, São Paulo Brazil, Phone: +551836363236, e-mail: lorrainepfaria@gmail. com
}

as Treatment Option for Crown-Root Fracture: Literature Review with Systematic Criteria. J Contemp Dent Pract 2015;16(9): 758-762.

\section{Source of support: Nil}

Conflict of interest: None

\section{INTRODUCTION}

Among the injuries involving the oral cavity, the dental alveolar trauma (DAT) is one of the most common, affecting about $30 \%$ of the population in most studies ${ }^{1,2}$ and the crown-root fracture (CRF) represents $5 \%$ of the cases. $^{3}$

The CRF is characterized by one or more fracture lines involving both root and crown portions ${ }^{4}$ may causing different types of damage to the tooth and support structures, such as lesions in the enamel, dentin and cementum, and there may be or not damage to the pulp. 5,6

Treatment of CRF requires interdisciplinary intervention involving several specialties, such as surgery, orthodontics, periodontics, prosthodontics, endodontics and pediatric. ${ }^{7}$ The approaches range from simple temporary stabilization of the injured tooth until definitive treatment which depends on the level where the fracture occurred. When the fracture occurs extensive deep the root fragment can be extracted or kept in position and getting coverage by bone tissue. ${ }^{8}$ But when the remaining root presents sufficient length to support a restorative treatment, may be performed gingivectomy with osteotomy, ${ }^{8}$ intentional reimplantation of the tooth ${ }^{9}$ or extrusion so that the treatment prosthetic-restorative could be more favorable. ${ }^{10}$

Regarding dental extrusion, it can be surgical ${ }^{3,5}$ and/ or orthodontic. ${ }^{11,12}$ The surgical extrusion has advantages of being more rapid and relatively simple operation, 13,14 whereas orthodontic extrusion is a very conservative treatment, with the advantage of allowing the gingival papilla keep circling the teeth, besides biological stability. ${ }^{11}$ 
Several clinical studies show that orthodontic extrusion is a viable method to keep the root and allow tooth restoration, ${ }^{15-17}$ but there is no strong scientific evidence to prove the effectiveness of the method. So, the aim of this study was to evaluate, by systematic review, the effectiveness and stability of orthodontic extrusion as treatment option for CRF.

\section{MATERIALS AND METHODS}

\section{Literature Search}

An electronic search was performed from August 2005 to 2014 by two evaluators (LPF and MMA) independently and conflicts were resolved by a third reviewer (MFA). The databases used were PubMed, cochraine central register of controlled trials and scopus using keywords: crown-root fracture and orthodontic extrusion.

The electronic search was supplemented by a manual search in the Journals Dental Traumatology for the periods from August 2013 to 2014.

Detailed search strategy: [('tooth crown' (MeSH Terms) or ('tooth' (All Fields) and 'crown' (All Fields)) or 'tooth crown' (All Fields) or 'crown' (All Fields) or 'crowns' (MeSH Terms) or 'crowns' (All Fields)) and ('plant roots' (MeSH Terms) or ('plant' (All Fields) and 'roots' (All Fields)) or 'plant roots' (All Fields) or 'root' (All Fields)) and ('fractures, bone' (MeSH Terms) or ('fractures' (All Fields) and 'bone' (All Fields)) or 'bone fractures' (All Fields) or 'fracture' (All Fields)) and ('orthodontic extrusion' (MeSH Terms) or ('orthodontic' (All Fields) and 'extrusion' (All Fields)) or 'orthodontic extrusion' (All Fields))) and (has abstract (text) and ('2005/08/01' (PDAT): '2014/08/31' (PDAT)) and English (lang)]

\section{Inclusion Criteria}

Case reports and studies with animal experiments that contained information about the crown-root fracture which were treated by orthodontic extrusion in permanent teeth fracture were included. Only articles in the English language and the abstract available were included.

\section{Exclusion Criteria}

Articles with secondary factors that interfered with the prognosis and treatment of the cases were excluded, such as periodontitis, inflammation, systemic diseases, bone fractures, previous trauma, and chronic use of any medication. In addition, were excluded clinical cases where there was no monitoring of the case, or in which the follow-up was less than 6 months, as well as animals experiments from those in which there was no monitoring of the case, or that the follow-up period was less than 60 days.

\section{DATA ANALYSIS}

For the data analysis of the articles, we evaluated the periodontal ligament space and the presence of bone or root resorption, dental loss, ankylosis, and pulp inflammation or infection problems. This analysis was clinical and radiographic.

\section{RESULTS}

\section{Level of Evidence}

The study included clinical cases with evidence level 4, based on the pyramid proposed by center-based health evidence-Cochrane. The absence of randomized controlled trials in this review was due to ethical issues involved in the management of trauma, mainly due to its unpredictability.

\section{Study Selection}

There were found 40 articles in PubMed and 38 articles were found in Scopus, so after removal of duplicate articles, our sample consisted of 51 articles. Out of these, 48 were excluded for not having orthodontic treatment, no follow-up or follow-up less than 6 months, or for not reporting the presence of crown and root fracture. In manual search in Dental Traumatology 20 articles were found, but none of them met the prerequisites established in this work. So, three articles formed the basis of our study (Flow Chart 1).

\section{Clinical Parameters Analyzed}

For the data analysis of each article, some clinical and radiographic parameters were selected and analyzed based on the results of each case. Thus, we evaluated the success of the procedures of orthodontic extrusion in the management of crown and root fracture (Table 1).

Flow Chart 1: Search flow chart

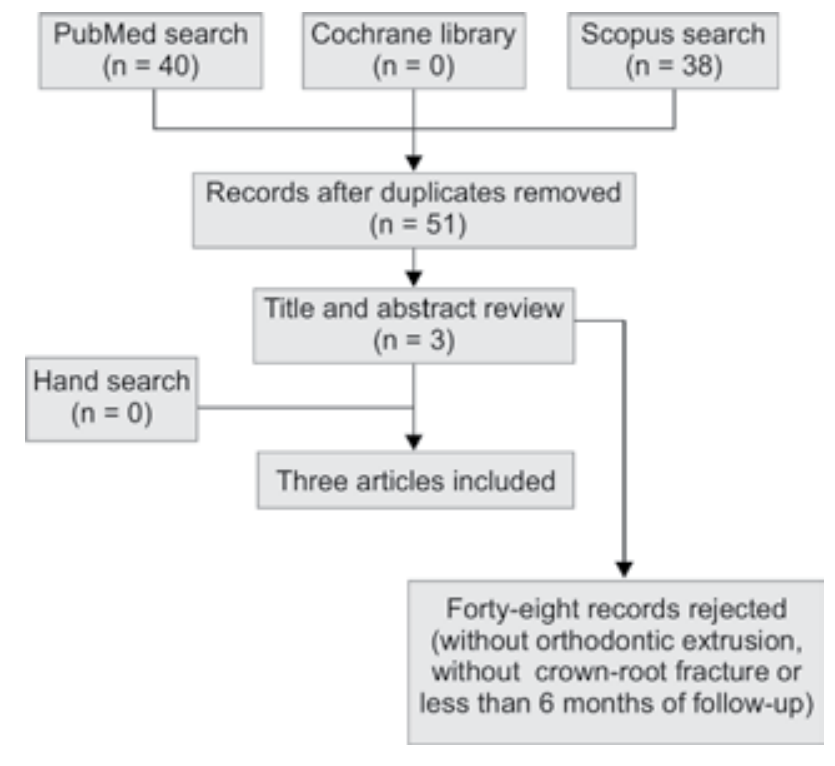


Table 1: Data extraction

\begin{tabular}{|c|c|c|c|}
\hline Authors & O'Toole S et al & Fidel SR et al & Saito CT et al \\
\hline Follow-up & 36 months & 36 months & 24 months \\
\hline Materials & $\begin{array}{l}\text { 18-year-old male; crown-root } \\
\text { fracture maxilary right canine; } \\
3.5 \mathrm{~mm} \text { extending subgingivally. } \\
\text { Tooth was vital, with no clinical and } \\
\text { radiographic symptoms or signs. }\end{array}$ & $\begin{array}{l}10 \text {-year-old male; crown-root } \\
\text { fracture in the left central incisor; } \\
\text { incomplete Apex formation; showed } \\
\text { slightly positive response to vitality } \\
\text { tests. }\end{array}$ & $\begin{array}{l}21 \text {-year-old female; } \\
\text { Oblique crown-root fracture, } 2 \mathrm{~mm} \\
\text { extending intraosseous, with pulp } \\
\text { exposure in the maxillary left central } \\
\text { incisor }\end{array}$ \\
\hline Treatment & $\begin{array}{l}\text { The maxillary teeth were bonded } \\
\text { with brackets of roth prescription. A } \\
\text { bracket was placed on the gingival } \\
\text { margin of the composite restoration } \\
\text { of the canine. The tooth was } \\
\text { extruded over a period of } 6 \text { months. } \\
\text { In the interim, the tooth fragment } \\
\text { was retained in plain water by the } \\
\text { patient.The original composite } \\
\text { resin restoration was removed. } \\
\text { The outline of the pulp chamber } \\
\text { was visible. Hard-setting calcium } \\
\text { hydroxide and resin-modified glass } \\
\text { ionomer were placed to dress and } \\
\text { seal the pulp. Both the tooth and the } \\
\text { fragment were prepared and bonded } \\
\text { together using a flowable composite } \\
\text { resin restoration material. }\end{array}$ & $\begin{array}{l}\text { Removed the coronal fragment, } \\
\text { then a cervical pulpotomy aiming to } \\
\text { achieve apexogenesis. One year } \\
\text { after, the radiographic examination } \\
\text { showed a periapical lesion on } \\
\text { the tooth and no evidence of } \\
\text { complete root formation. The root } \\
\text { canal was prepared and dressed } \\
\text { with a calcium hydroxide during } \\
6 \text { months aiming at apexification } \\
\text { As the maxillary left central incisor } \\
\text { exhibited normal healing, the } \\
\text { orthodontic extrusion was initiated. } \\
\text { Brackets were placed from the } \\
\text { maxillary right canine to the left } \\
\text { canine and a low intensity force was } \\
\text { applied. After } 16 \text { weeks, extrusion } \\
\text { was completed. On examination } \\
\text { at } 1 \text { year and } 8 \text { months after the } \\
\text { trauma, the maxillary left central } \\
\text { incisor presented pulp necrosis and } \\
\text { conventional endodontic treatment } \\
\text { was performed. }\end{array}$ & $\begin{array}{l}\text { Endodontic treatment was perfomed } \\
\text { and definitive root canal obturation } \\
\text { with gutta-percha points and } \\
\text { Sealapex. Orthodontic extrusion } \\
\text { was performed using a fixed } \\
\text { appliance. Orthodontic extrusion } \\
\text { was terminated when all root } \\
\text { margins were exposed, which was } \\
\text { achieved within } 21 \text { days. the tooth } \\
\text { was splinted with composite resin for } \\
12 \text { weeks and a mucoperiosteal flap } \\
\text { repositioning surgery was performed } \\
\text { in the area surrounding the extruded } \\
\text { tooth. The treatment was completed } \\
\text { with post space preparation and } \\
\text { cementation of a metallic radicular } \\
\text { post to provide resistance to the } \\
\text { fractured tooth. }\end{array}$ \\
\hline $\begin{array}{l}\text { Pulp vitality after } \\
\text { treatment }\end{array}$ & Present & Absent & Absent \\
\hline Outcome & $\begin{array}{l}\text { Three years post-treatment the } \\
\text { tooth remains vital, in function } \\
\text { and displaying no adverse } \\
\text { signs or symptoms clinically or } \\
\text { radiographically. }\end{array}$ & $\begin{array}{l}\text { Clinical and radiographic } \\
\text { examination showed healthy tissues } \\
\text { and teeth, and no evidence of apical } \\
\text { periodontitis. }\end{array}$ & $\begin{array}{l}\text { Clinical and radiographic showed } \\
\text { a good adaptation of the tooth } \\
\text { fragment/ composite resin } \\
\text { restoration, absence of radiographic } \\
\text { signs of root resorption and absence } \\
\text { of painful symptomatology. }\end{array}$ \\
\hline
\end{tabular}

Periodontal ligament space: No changes in the periodontal ligament space in all articles included.

Presence of bone resorption: Absence of bone resorption in all the articles included.

Dental loss: Absence of tooth loss in all the articles included.

Ankylosis: Absence of ankylosis in all articles included.

Pulp vitality: Previously to treatment, all studies showed pulp vitality, and in the study of Fidel et al this vitality showed itself slightly to the tests. After the treatment, only the clinical case of $\mathrm{O}^{\prime}$ Toole $\mathrm{S}$ et al, ${ }^{19}$ proved vital. The other two cases executed endodontic treatment.

Inflammation or pulpal or periradicular infections: Clinical cases of $\mathrm{O}^{\prime}$ Toole et $\mathrm{al}^{19}$ and clinical cases of Saito et $\mathrm{al}^{20}$ had no reports of pulp and periradicular lesions or infections. However, the case of Fidel et $\mathrm{al}^{18}$ showed periapical 1 year and 8 months after treatment, and then done the conventional endodontic treatment that proved to be effective and satisfactory.

\section{DISCUSSION}

Some factors influenced the choice of treatment, being very important for the prognosis of the treatment. In the case of Saito et $\mathrm{al}^{20}$ and $\mathrm{O}^{\prime}$ Toole et $\mathrm{al}^{19}{ }^{19}$ teeth showed complete root formation, thus this was not a determining factor in the choice of treatment. However, in the case of Fidel et al, ${ }^{18}$ incomplete root formation was decisive for the choice of treatment. As there were pulp vitality, it was possible to achieve apexogenesis ${ }^{21}$ thereby Fidel et $\mathrm{al}^{18}$ proposed pulpotomy and pulp covered with calcium hydroxide. However, a year later, the apex remained open and noted the presence of the periapical lesion. Therefore, the author opted for the filling of the canal with calcium hydroxide with successive exchanges for 6 months. Having then the healing of the inflammatory process and complete formation of the apex, was initiated the orthodontic extrusion.

Still in relation to pulp conditions, Fidel et $\mathrm{al}^{18}$ during the extrusion (after the complete formation of the apex) noted periapical lesion in his patient, causing him to 
replace the Calcium Hydroxide by an endodontic filling. In the case of Saito et $\mathrm{al}^{20}$ there was pulp exposure and the tooth initially received emergency treatment (removal of coronal pulp and application of folder-based calcium hydroxide) and after, complete endodontic treatment prior to orthodontic extrusion. In the case $\mathrm{O}^{\prime}$ Toole et al, ${ }^{19}$ the pulp was visible but not exposed. So, they opted for the protection of the pulp-dentin complex with hydroxide calcium and resin with glass ionomer. Thus, was kept pulp vitality prior to extrusion, which is maintained even after finalization of treatment.

These procedures are in accordance with the International Association of Dental Traumatology guidelines for the management of traumatic dental injuries, ${ }^{8}$ which shows that in cases in which there is no complete root formation, it is advantageous the seek for the preservation of pulp vitality seeking apexification.

Just as the choices Saito et $\mathrm{al}^{20}{ }^{20}$ who have opted to perform endodontic treatment since there were pulp exposure and also choices $\mathrm{O}^{\prime}$ Toole, that there is no exposure, chose to maintain pulp vitality and perform orthodontic extrusion without obturation.

In relation to the orthodontic technique, Fidel et $\mathrm{al}^{18}$ opted for placing intracanal pin, with composite resin restoration and placement of brackets from canine to canine. The force applied was of low intensity and the extrusion was completed after 16 weeks. Then, the tooth was restored with prosthetic crown and pin system.

Saito et $\mathrm{al}^{20}$ opted for fragment bonding and complemented with composite resin. Then, the orthodontic extrusion was performed to restore the biological space. An orthodontic stainless steel wire was fixed with lightcured composite resin to the palatal surface of the maxillary central incisor and right maxillary left lateral incisor to provide the necessary anchorage for tooth movement, and a stainless steel was bent to form a loop and had a root extension $4 \mathrm{~mm}$. Then orthodontic elastic was placed $1 / 8$ in diameter through the coronal and tied the bow tie between neighboring teeth. The elastic band was changed once a week and orthodontic extrusion was terminated after 21 days. After restoring the biological space, the tooth was immobilized for 12 weeks. Cuoghi et al ${ }^{17}$ performed the technique similarly also changing the elastic weekly and ending the extrusion at 6 weeks.

However, $\mathrm{O}^{\prime}$ Toole et $\mathrm{al}^{19}$ chose to restore the tooth with composite, and then put brackets on maxillary teeth. Extrusion was carried out for 6 months. The coronal fragment was kept in water during that period. After extrusion, the tooth and fragment were prepared with adhesive, after being aligned, were bonded with resin flow.
These orthodontic techniques are in accordance with those described by Bach et $\mathrm{al}^{22}{ }^{22}$ which states that there are several methods for the extrusion is performed, however, these techniques should be chosen according to each case, using different means to get the necessary strength for extrusion.

From the results of this review, and variability of information there is a need for more studies on the subject, so that factors, such as time of tooth movement, types of equipment being used and the need to perform endodontic treatment are established according to each case.

\section{CONCLUSION}

According to this review, orthodontic extrusion could be an effective and stable method as treatment for crownroot fracture, however, due to the low level of evidence of the studies included in this review, more studies should be conducted on this subject.

\section{REFERENCES}

1. Granville-Garcia AF, Vieira IT, Siqueira MJ, de Menezes VA, Cavalcanti AL. Traumatic dental injuries and associated factors among Brazilian preschool children aged 1-5 years. Acta Odontol Latinoam 2010;23:47-52.

2. Glendor U, Andersson L. Public health aspects of oral diseases and disorders: dental trauma. In: C. Pine, R. Harris, editors. Community Oral Health. London: Quintessence Publishing; 2007. p. 203-211.

3. Kirzioglu Z, Karayilmaz H. Surgical extrusion of a crown-root fractured immature permanent incisor: 36 months follow-up. Dent Traumatol 2007;23:380-385.

4. Andreasen JO, Andreasen FM, Andersson L. Textbook and color atlas of traumatic injuries to the teeth. 4th ed. Oxford: Blackwell; 2007.

5. Das B, Muthu MS. Surgical extrusion as a treatment option for crown-root fracture in permanent anterior teeth: a systematic review. Dent Traumatol 2013;29:423-431.

6. Spinas E, Altana M. A new classification for crown fractures of teeth. J Clin Pediatr Dent 2002;26:225-231.

7. Andreasen JO, Lauridsen E, Gerds TA, Ahrensburg SS. Dental Trauma Guide: a source of evidence-based treatment guidelines for dental trauma. Dent Traumatol 2012;28:345-350.

8. Diangelis AJ, Andreasen JO, Ebeleseder KA, et al. International Association of Dental Traumatology guidelines for the management of traumatic dental injuries: 1 . Fractures and luxations of permanent teeth. Dent Traumatol 2012;28:2-12.

9. Wang Z, Heffernan M, Vann WF Jr. Management of a complicated crown-root fracture in a young permanent incisor using intentional replantation. Dent Traumatol 2000;24: 100-103.

10. Andreasen JO, Andreasen FM. Crown-root fractures. In: Andreasen JO, Andreasen FM, editors. Text book and color atlas of traumatic injuries to the teeth. 3rd ed. Copenhagen: Munksgaard; 1993. p. 257-277

11. Arhun N, Arman A, Ungor M, Erkut S. A conservative multidisciplinary approach for improved aesthetic results with traumatised anterior teeth. Br Dent J 2006;201:509-512. 
12. Bielicka B, Bartlowiak M, Urban E, Tomaszi M. Holistic approach in the management of subgingivally fractured premolar tooth: case report. Dent Med Probl 2008;45: 211-214.

13. Yuan LT, MoDuan D, Tan L, Wang XJ, Wu LA. Treatment for a complicated crown-root fracture with intentional replantation: a case report with a 3.5 year follow-up. Dent Traumatol 2013; 29:474-478.

14. Kim DS, Shin DR, Choi GW, Park SH, Lee JW, Kim SY. Management of complicated crown-root fractures using intentional replantation: two case reports. Dent Traumatol 2013;29:334-337.

15. Suprabha BS, Kundabala M, Subraya M, Kancherla P. Reattachment and orthodontic extrusion in the management of an incisor crown-root fracture: a case report. J Clin Pediatr Dent 2006;30:211-214.

16. Poi WR, Cardoso LC, Castro JC, Cintra LT, Gulinelli JL, Lazari JA. Multidisciplinary treatment approach for crown fracture and crownroot fracture: a case report. Dent Traumatol 2007;23:51-55.

17. Cuoghi OA, Bosco AF, de Mendonça MR, Tondelli PM, Miranda-Zamalloa YM. Multidisciplinary treatment of a fractured root: a case report. Aust Orthod J 2010;26:90-94.

18. Fidel SR, Fidel-Junior RA, Sassone LM, Murad CF, Fidel RA. Clinical management of a complicated crown-root fracture: a case report. Braz Dent J 2011;22:258-262.

19. O'Toole S, Garvey T, Hashem A. The multidisciplinary conservative management of a vital crown root fracture. Dent Update 2013;40:584-586.

20. Saito CT, Guskuma MH, Gulinelli JL, et al. Management of a complicated crown-root fracture using adhesive fragment reattachment and orthodontic extrusion. Dent Traumatol 2009;25:541-544.

21. Rafter M. Apexification: a review. Dent Traumatol 2005;21:1-8.

22. Bach N, Baylard JF, Voyer R. Orthodontic extrusion: periodontal considerations and applications. J Can Dent Assoc 2004;70:775-780. 